\title{
Small invertebrates in bivalve-cultivated and unmodified habitats of nearshore ecosystems
}

\author{
Stuart H. Munsch $\mathbb{D} \cdot$ Julie S. Barber $\cdot$ Jeffery R. Cordell $\cdot$ Peter M. Kiffney $•$ \\ Beth L. Sanderson · Jason D. Toft
}

Received: 27 July 2020/Revised: 30 December 2020/Accepted: 17 January 2021/Published online: 22 February 2021

(C) The Author(s) 2021

\begin{abstract}
Many nearshore ecosystems are modified by aquaculture, including bivalve culture to produce food and restore extirpated populations. Small invertebrates in nearshore ecosystems support fundamental ecological processes, but the effects of bivalve culture on invertebrates are incompletely understood. Here, we compared invertebrate assemblages from multiple studies of bivalve-cultivated and unmodified nearshore habitats along the US west coast. In general, unmodified eelgrass and nearby off-bottom culture habitats with eelgrass present were inhabited by a greater abundance, richness, and diversity of epibenthic invertebrates than bottom culture and bare (mud, sand) habitats that both lacked eelgrass. Findings of individual studies suggested: minor differences in
\end{abstract}

Handling editor: Jonne Kotta

Supplementary Information The online version of this article (https://doi.org/10.1007/s10750-021-04520-1) contains supplementary material, which is available to authorized users.

S. H. Munsch ( $\square)$

Ocean Associates Inc, Under Contract to Northwest

Fisheries Science Center, National Marine Fisheries

Service, NOAA, 2725 Montlake Boulevard East, Seattle,

WA 98112, USA

e-mail: Stuart.Munsch@NOAA.gov

J. S. Barber

Fisheries Department, Swinomish Indian Tribal

Community, 11426 Moorage Way, La Conner,

WA 98221, USA epibenthic invertebrate assemblages associated with various aquaculture practices; restoring native oysters to mudflats did not detectably alter epibenthic invertebrate abundances; epibenthic invertebrates were more abundant on shell hash introduced to mudflats than unmodified mudflats; and benthic invertebrates were less abundant, rich, and diverse in habitats cultured on bottom by Manila clams. Considering the range of these patterns, there appears to be potential for coastal communities to restore extirpated bivalve populations or develop bivalve culture practices that meet objectives to grow food while maintaining nearshore ecosystems' fundamental processes supported by robust invertebrate assemblages.

Keywords Aquaculture - Eelgrass - Harpacticoida · Olympia oyster $\cdot$ Pacific oyster $\cdot$ Manila clam

\author{
J. R. Cordell · J. D. Toft \\ School of Aquatic and Fishery Sciences, University of \\ Washington, 1122 NE Boat St, Seattle, \\ WA 98105, USA \\ P. M. Kiffney · B. L. Sanderson \\ Fish Ecology Division, Northwest Fisheries Science \\ Center, National Marine Fisheries Service, NOAA, 2725 \\ Montlake Boulevard East, Seattle, WA 98112, USA
}




\section{Introduction}

Small invertebrates are an important component of nearshore ecosystems. The interface of terrestrial, aquatic, and benthic realms often provides a diverse productivity base (e.g., algae and seagrasses, beach wrack, leaf litter) and structure (e.g., biogenic habitats, interstitial spaces) that small invertebrates use to form dense assemblages (Beck et al., 2001). These invertebrates, often including amphipods, harpacticoid copepods, and polychaetes, are then available as prey to other species, such as juvenile fish (Simenstad et al., 1982; Gee, 1989; Nunn et al., 2012; Kennedy et al., 2018). Indeed, invertebrates are a vital prey for fish, and fuel migration, growth, and reproduction (Wissmar \& Simenstad, 1988; Sheaves et al., 2015; Scharf et al., 2006). In addition to abundance, invertebrate diversity is important. Predators exploit a variety of invertebrates (e.g., D’Aguillo et al., 2014, Selleslagh et al., 2015), which may provide a stable prey base despite variation in individual species abundances across time and space (sensu Schindler et al., 2015). Thus, functional nearshore habitats enable abundant, diverse invertebrate assemblages that support nutrient and energy flow across habitat types and consumers.

Bivalve propagation occurs across the world's nearshore ecosystems. Along the US west coast, there are two primary reasons for culturing bivalvesmainly for aquaculture to enhance food production and also for restoration to re-establish extirpated populations. Relevant to our study, farmers grow nonnative Pacific oyster Crassostrea gigas (Thunberg, 1793) and Manila clam Ruditapes philippinarum (Adams and Reeve 1850) for food and economic value, and restoration efforts are underway to reestablish Olympia oysters Ostrea lurida Carpenter, 1864 , a culturally significant species that once provided substantial cultural, ecological, and economic values to the US west coast (Pritchard et al., 2015). Olympia oysters have been harvested by Indigenous populations for millennia and were commercially important from the $1800 \mathrm{~s}$ to the early $1900 \mathrm{~s}$. However, like many other oysters, they have declined as a consequence of overexploitation, habitat destruction, and displacement by non-native bivalve species (Ruesink et al., 2005; White et al., 2009; Zu Ermagassen et al., 2012). Thus, bivalve culture is widely practiced to produce food or restore extirpated populations.
Bivalve culture may influence invertebrate assemblages by altering the biophysical environment of nearshore ecosystems (Simenstad and Fresh, 1995; Dumbauld et al., 2009; Forrest et al., 2009; Gallardi, 2014). Culture introduces novel structures (e.g., bags, buoys, lines, nets, posts) and structure is a fundamental determinant of invertebrate assemblages (e.g., Heery et al., 2017). Indeed, culture of shelled bivalves like oysters placed on soft-sediment habitats may essentially replace soft-bottom ecosystems with hard-bottom ecosystems that are often inhabited by productive infauna and epifauna (Gallardi, 2014). Novel structures can also introduce shading and alter topography, further influencing invertebrate assemblages (Forrest et al., 2009; Cordell et al., 2017a, b). Also, culturing filter feeders such as bivalves concentrates their waste, which aggregates on the bottom and changes the physio-chemical characteristics of the benthos (Forrest et al., 2009). Cultured species that live in the benthos (e.g., burrowing clams) may also compete for space with benthic invertebrates and their harvest (e.g., digging) often disturbs the benthos, which can decrease benthic invertebrate abundances (Griffiths et al., 2006). Practices associated with culture can also influence the invertebrate community. For example, the netting used to protect bottom-cultured clams can support biogenic habitats that in turn support higher abundances of invertebrates than unstructured habitats (Powers et al., 2007). Overall, bivalve culture may influence the nearshore invertebrate community via multiple mechanisms and effects on invertebrates are likely to depend on ecological context.

As the human population grows, so too does the need for sustainable sources of protein that potentially include bivalve aquaculture (Shumway et al., 2003). Additionally, coastal ecosystems and human communities stand to benefit from re-establishing extirpated populations including Olympia oysters (White et al., 2009). However, effects of culture on invertebrates remain understudied (but see Simenstad and Fresh, 1995; Dumbauld et al., 2009; Forrest et al., 2009) and nearshore ecosystems are places of substantial ecological change, important habitats, and therefore conservation concern (Lotze et al., 2006). Importantly, bivalve culture may enhance or degrade ecological attributes or interactions, such as increasing or limiting habitat for small invertebrates that serve as key components of nearshore food webs (Dumbauld et al., 2009). A clearer understanding of how bivalve 
culture influences invertebrate assemblages will therefore inform decisions that seek to expand and develop sustainable culture practices, and shed light on ecological processes associated with restoring shellfish populations.

Here, we took advantage of multiple case studies to compare invertebrate assemblages among bivalvecultivated and unmodified habitats of nearshore ecosystems along the US west coast. First, we synthesized comparable data (e.g., consistent methods, similar habitat groupings) from these case studies to detect coherent patterns across the region. In this synthetic study we asked "How does invertebrate composition, abundance, richness, and diversity vary among bare, on-bottom culture, off-bottom culture, and eelgrass habitats?" Second, we reported the findings of individual studies that examined studyspecific influences of culture practices on the invertebrate assemblage. We used six case studies in Puget Sound, WA, and one case study that spanned four locations along the US west coast. The focus of these studies was often on invertebrates that comprise prey for fish such as juvenile Pacific salmon Oncorhynchus spp. (e.g., Simenstad et al., 1982; Toft et al., 2007) that are of cultural, ecological, and economic importance and in many places declining (Nehlsen et al., 1991). Our goal was to provide baseline knowledge for ecologists working in cultured systems, as well as managers charged with optimizing for food production, enhancing economic returns, re-establishing extirpated bivalves, and protecting functional nearshore ecosystems.

\section{Methods}

\section{Overall approach}

We analyzed the data from seven studies that compared invertebrate assemblages in cultured and adjacent reference habitats (Table 1; Fig. 1). The studies were designed to sample invertebrates across cultured and unmodified (e.g., eelgrass, mudflats) habitats to quantify among-habitat assemblage differences. Some studies were also designed to examine patterns associated with farming methods. We first examined patterns in invertebrate assemblages that emerged from observations combined across studies that similarly sampled invertebrates on the surface of the bottom (i.e., epibenthos). Notably, in this opportunistic, synthetic analysis, habitat types and farming methods were not represented evenly across the original studies. Then, following the original studies' purposes and design (described below), we examined patterns in invertebrate assemblages among treatments and habitats.

Invertebrate sampling followed protocols developed by scientists at the UW School of Aquatic and Fishery Sciences (https://sites.google.com/a/uw.edu/ toolbox/protocols/epibenthic-invertebrates), briefly described below. To sample epibenthic invertebrates, researchers used a 7,571 $1 \mathrm{~h}^{-1} 12$-volt electric bilge pump, housed at the top of a $14.8 \mathrm{~cm}$ wide PVC sampling cylinder, open only at the base, which sampled the water $\sim 25 \mathrm{~cm}$ above the bottom and encompassed an area of $0.018 \mathrm{~m}^{2}$ of the benthic substrate (hereafter: "epibenthic pump"). The sampling cylinder was equipped with $0.106 \mathrm{~mm}$ mesh screening over replacement water ports, allowing a quantitative sample of the enclosed epibenthos to be obtained without external contamination. For each sample, the cylinder was gently placed on the sediment surface, and water was pumped for $20 \mathrm{~s}$, or until benthic sediments were noticed in the pump's clear plastic outflow hose. Material from the pump was collected on a $0.106 \mathrm{~mm}$ sieve and the filtrate was fixed in a $5 \%$ buffered formaldehyde solution. In the laboratory, invertebrates were identified to the species level for most adult crustaceans (e.g., gammarid amphipods, tanaids, harpacticoid copepods) and to family or higher taxonomic categories for other groups. Strictly planktonic (e.g., most calanoid copepods) or benthic (e.g., nematodes) organisms were not targeted by the sampling methodology, and were not enumerated. At the Samish Bay Manila clam farm (see below), sediment cores were extracted to sample benthic species. This consisted of inserting a PVC pipe $5 \mathrm{~cm}$ in diameter and $10 \mathrm{~cm}$ in length into the substrate and extracting the contents, which were preserved in 5\% buffered formaldehyde solution. (Note these benthic samples are not used in the synthetic analysis). In the laboratory, samples were sieved through $0.5 \mathrm{~mm}$ mesh, counted, and identified to species for adult crustaceans and polychaete annelids and to higher taxonomic levels for other groups. Invertebrate identification and enumeration for all studies were conducted by the same group and supervised by one of the authors (JRC). 
Table 1 Descriptions of the case studies

\begin{tabular}{|c|c|c|c|c|c|c|}
\hline Study & $\begin{array}{l}\text { Culture } \\
\text { purpose }\end{array}$ & Locations & Years & Months & Sampling & $\begin{array}{l}\text { Habitat observations } \\
\text { contributed to } \\
\text { synthetic study }\end{array}$ \\
\hline Pacific oyster longline & Aquaculture & $\begin{array}{l}\text { Humboldt, Samish, } \\
\text { Tillamook, \& } \\
\text { Willapa Bays }\end{array}$ & 2016 & $\begin{array}{l}\text { June- } \\
\text { August }\end{array}$ & Epibenthic & $\begin{array}{l}\text { Eelgrass, off-bottom } \\
\text { culture }\end{array}$ \\
\hline $\begin{array}{l}\text { Pacific oyster flipbag vs. } \\
\text { longline }\end{array}$ & Aquaculture & Samish Bay & 2017 & April & Epibenthic & $\begin{array}{l}\text { Eelgrass, off-bottom } \\
\text { culture }\end{array}$ \\
\hline $\begin{array}{l}\text { Pacific oyster shell } \\
\text { introduction }\end{array}$ & $\begin{array}{l}\text { Re-establish } \\
\text { Olympia } \\
\text { oysters }\end{array}$ & $\begin{array}{l}\text { Dogfish \& Liberty } \\
\text { Bays, Virginia Pt. } \\
\text { Cove }\end{array}$ & $\begin{array}{l}2009, \\
2010, \& \\
2012\end{array}$ & $\begin{array}{r}\text { April- } \\
\text { May }\end{array}$ & Epibenthic & Bottom culture, bare \\
\hline Olympia oyster BACI one & $\begin{array}{l}\text { Re-establish } \\
\text { Olympia } \\
\text { oysters }\end{array}$ & $\begin{array}{l}\text { Dogfish \& Lemolo } \\
\text { Bays }\end{array}$ & $\begin{array}{c}2006 \& \\
2007\end{array}$ & $\begin{array}{l}\text { April- } \\
\text { May }\end{array}$ & Epibenthic & Bottom culture, bare \\
\hline Olympia oyster BACI two & $\begin{array}{l}\text { Re-establish } \\
\text { Olympia } \\
\text { oysters }\end{array}$ & $\begin{array}{l}\text { Kiket Lagoon, Lone } \\
\text { Tree Lagoon, \& } \\
\text { Turners Bay }\end{array}$ & $\begin{array}{l}2015, \\
2016, \\
2017, \& \\
2018\end{array}$ & $\begin{array}{c}\text { March- } \\
\text { April }\end{array}$ & Epibenthic & Bottom culture, bare \\
\hline $\begin{array}{l}\text { Manila clam unfarmed vs. } \\
\text { hand harvest vs. } \\
\text { mechanical harvest }\end{array}$ & Aquaculture & Samish Bay & $\begin{array}{c}2011 \& \\
2012\end{array}$ & $\begin{array}{r}\text { May- } \\
\text { July }\end{array}$ & Benthic & None \\
\hline $\begin{array}{l}\text { Manila clam eelgrass, sand, } \\
\& \text { anti-predator netting }\end{array}$ & Aquaculture & Samish Bay & $\begin{array}{c}2011 \& \\
2012\end{array}$ & $\begin{array}{l}\text { May- } \\
\text { July }\end{array}$ & Epibenthic & $\begin{array}{l}\text { Eelgrass, bottom } \\
\text { culture, bare }\end{array}$ \\
\hline
\end{tabular}

Separate case study designs were as follows:

Pacific oyster longline

The purpose of this study was to quantify the effects of two Pacific oyster aquaculture farming techniquesflipbag and longline-on epibenthic invertebrates at four sites along the US west coast. Longline culture consisted of oysters settled on cultch directly attached to ropes that were suspended $\approx 0.5 \mathrm{~m}$ above the sediment and supported by a series of posts. Although information on line spacing at each study site was not recorded, individual longlines are generally separated by $\approx 75-150 \mathrm{~cm}$. Epibenthic invertebrates were sampled at Samish Bay (WA), Willapa Bay (WA), Tillamook Bay (OR), and Humboldt Bay (CA). Each site included longline Pacific oyster aquaculture and a nearby eelgrass Zostera marina Linnaeus, 1753 meadow as a reference site. Three strata-aquaculture, edge, and eelgrass, were sampled via epibenthic pump. The longline oyster aquaculture site was selected within each estuary to meet the following criteria: (1) presence of similarly aged 2-year-old oysters, (2) presence of adjacent eelgrass, (3) a discernable edge between aquaculture and eelgrass, (4) access to sites permitted by the oyster growers, (5) physical consistency (e.g., similar tidal elevation), and (6) biological consistency (e.g., sufficient continuous eelgrass). Eelgrass was most dense outside aquaculture, but present in all strata. Mean shoot densities varied by estuary but ranged from $\approx 15-45,20-65$, and 30-95 shoots per $\mathrm{m}^{2}$ in aquaculture, edge, and eelgrass strata, respectively (Hudson et al., 2018). Due to fieldwork logistics, invertebrate sampling did not occur in the same exact places as eelgrass measurements so we did not incorporate these values into analyses. As tidal windows allowed, researchers collected 6-10 samples from each stratum per site. Each site was sampled in one day and all sites were sampled between 22 June and 2 August 2016.

Pacific oyster flipbag versus longline

The purpose of this study was to quantify differential effects on epibenthic invertebrates of two Pacific oyster aquaculture farming techniques: flipbag and longline. Longline culture was as described above and flipbag culture is a technique where oysters are grown 
Fig. 1 Invertebrate

sampling locations along the US west coast

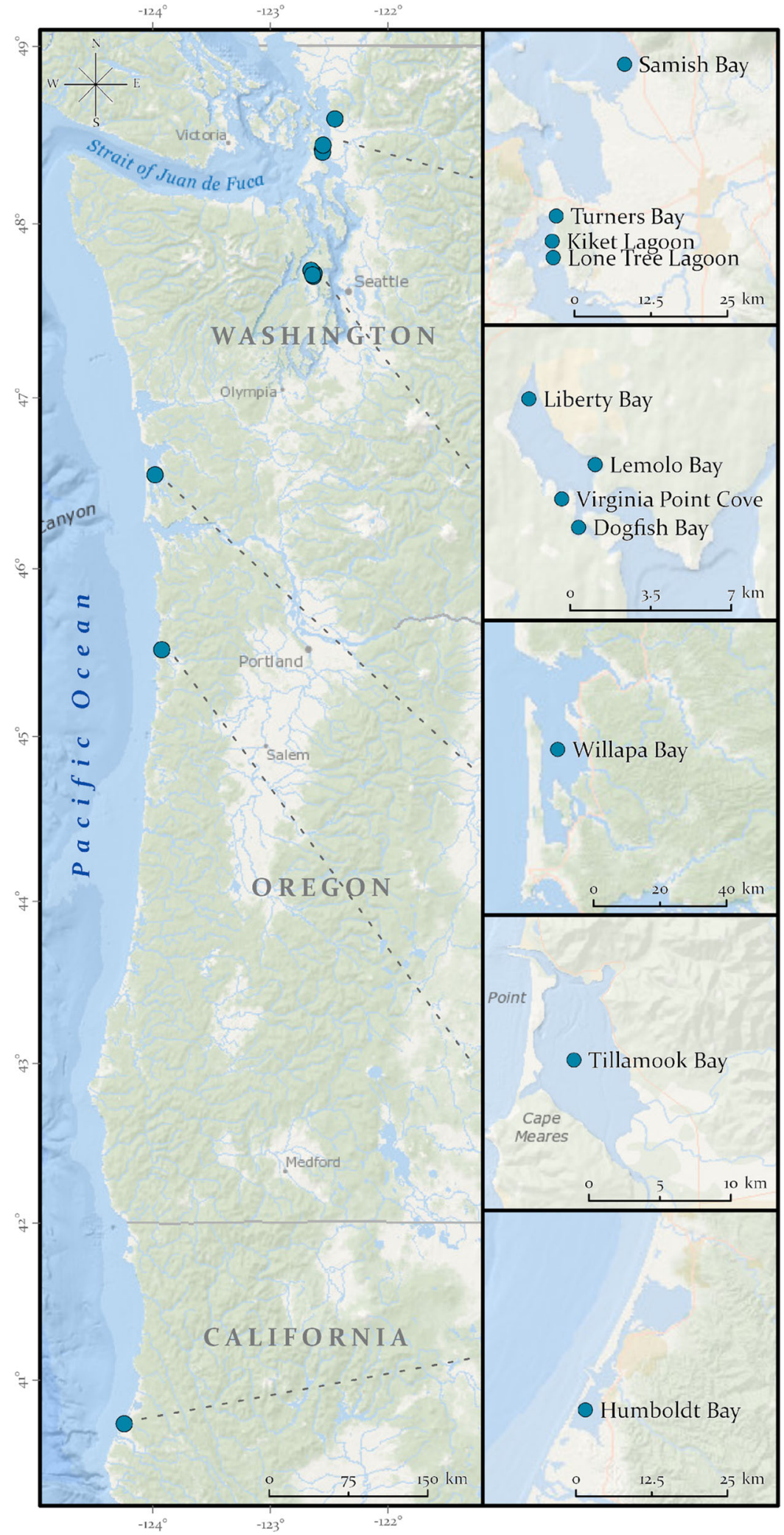


in plastic, mesh bags suspended by a rope, with attached buoys that enable the bags to rise and fall with the tides. Sampling occurred in Samish Bay and followed the same epibenthic pump protocol to collect invertebrates in oyster, edge, and eelgrass strata. Researchers sampled on 27 April 2017, collecting ten samples in each combination of strata (oyster, edge, eelgrass) and aquaculture type (line, flipbag). Eelgrass was present in all strata, with mean shoot densities across strata of $\approx 45,35$, and 100 shoots per $\mathrm{m}^{2}$ in aquaculture, edge, and eelgrass strata, respectively (Hudson et al., 2018). As before, we provide these numbers for general context but did not incorporate them into analyses. Since the flipbag site was located close to a creek mouth, which may have altered its invertebrate assemblage, we focused the analyses on comparisons among aquaculture strata within sites instead of between culture methods.

\section{Pacific oyster shell introduction}

The purpose of this study was to compare epibenthic invertebrates between mud and Pacific oyster shell habitats, as introducing shell is a technique used to enhance native oyster recruitment. Pacific oyster shells designed to cover $80 \%$ of the benthos with zero to three layers were introduced by sluicing cultch (i.e., shells that provide attachment points to facilitate oyster recruitment) from barges at two sites: Dogfish and Liberty Bays that were two and eight acres in area, respectively. Cultch was unseeded and intended to recruit Olympia oysters from small nearby populations. A reference site, Virginia Point Cove, where shells were not introduced, was also monitored. Eelgrass was not present at any of these sites. Invertebrate samples were collected from shells and mud (untreated) substrates using the epibenthic pump protocol described above, taking 5-16 samples in late April-May 2009, 2010, and 2012.

\section{Olympia oyster restoration experiments}

The purpose of these two studies was to test for an effect of restoring native Olympia oyster habitat on epibenthic invertebrates. The study design was "before-after-control-impact" (BACI; Green, 1979), whereby researchers monitored sites before and after the re-establishment of oysters using the epibenthic pump. We use the term "re-establishment" to indicate that Olympia oysters were restored to a region where they have been extirpated, although we cannot be sure of their exact, probably dynamic, historical locations. In Study One, researchers sampled two directly adjacent locations in west central Puget Sound: Dogfish and Lemolo Bays. Within each site, there were two plots: one that received Pacific oyster shells seeded with Olympia oysters and a control that did not. As before, shells were introduced by sluicing cultch from a barge to cover $\approx 80 \%$ of the benthos zero to three layers thick. Seven samples were taken at each plot within each site in April and May of 2006 and 2007, and reintroduction occurred between the 2 years. In Study Two, researchers sampled three locations in Skagit Bay within Puget Sound: Kiket Lagoon, Lone Tree Lagoon, and Turners Bay. Twenty-four samples were taken at each site in March and April of 2015, 2016, 2017, and 2018. Olympia oysters were re-established in Kiket and Lone Tree Lagoons in 2016 (following sampling), leaving Turners Bay as a reference that did not receive oysters. In this study, Olympia oysters were re-established as seed on Pacific oyster shell and spread in $\approx 1-2$ layers (80-100\% cover) on the benthos in restoration beds. In 2017, the restoration beds in Kiket and Lone Tree Lagoons covered $101.1 \mathrm{~m}^{2}$ and $154.1 \mathrm{~m}^{2}$, respectively. Epibenthic samples, however, were taken from $2 \mathrm{~m}^{2}$ experimental plots that were located within the restoration sites but not in the larger restoration beds. Note that the methodologies between the two studies differed slightly-in BACI Study One, a control was established by not introducing oysters in a portion within each of the two sites; in BACI Study Two, a control was established by not introducing oysters at one of the three sites. Eelgrass was not present in any of these sites.

Manila clam, eelgrass, sand, and anti-predator netting

The purposes of this study were to quantify: (1) epibenthic invertebrates in Manila clam aquaculture, eelgrass, and sand habitats, and (2) effects of sweeping seaweed biofouling off anti-predator nets on epibenthic invertebrates. In June and July 2011 and May 2012, epibenthic pump samples were collected in Samish Bay from plots with anti-predator netting. One plot on which algae had been removed via a tractor with a modified street sweeper attachment ("swept"), 
and one plot that had not been swept ("un-swept"), were sampled on each date. Two unfarmed reference substrata, eelgrass and bare sand, adjacent to the farm were also sampled. There was no eelgrass in the farmed areas. In each case the epibenthic pump sampled seven replicate samples.

Benthic study: Manila clam unfarmed versus hand harvest versus mechanical harvest

The purposes of this study were to compare (1) benthic invertebrate communities in Manila clam farmed and unfarmed habitats, (2) quantify effects of clam harvest on benthic invertebrates, and (3) quantify effects of mechanical and hand harvest on benthic invertebrates. With respect to the latter two, culturists developed a harvest technique using a modified tulip bulb tractor that was more efficient than conventional harvest by hand (Saurel et al., 2014). The study examined whether harvest itself or the harvest technique (mechanical vs. hand) altered the benthic invertebrate assemblage. Researchers also sampled a reference area, composed of sand and sparse eelgrass, and aquaculture plots undergoing harvest where (a) some of the plot was harvested mechanically and (b) some of the plot was harvested by hand.

To sample benthic invertebrates, researchers extracted benthic cores in Samish Bay in June and July 2011 and May 2012. In each of these months, seven samples were taken at each stratum. Pre- and post-harvest strata were sampled the day before and day after harvest, respectively.

\section{Analysis}

Our general approach was to compare invertebrate assemblages among cultured and unmodified habitats while accounting for data structure. We used multivariate statistical methods to detect differences in assemblage composition and univariate methods to detect differences in counts, richness, and diversity. We examined singular studies consistently with how they were designed and, to provide an additional, broader perspective, we conducted a synthetic analysis using data from all studies that sampled the epibenthos (i.e., excluding the benthic study) and that were collected directly on culture or reference locations (e.g., excluding "edge" strata occurring at the border of the two). We binned observations in the synthetic analysis into four habitat types: eelgrass, off-bottom culture (flipbag, line), bottom culture (oyster shell, Olympia oysters, Manila clams), and bare (sand, mud) as described in Table 1. Though traditional bottom culture of Pacific oysters was not represented, bottom culture was the broadest bin and included the most diverse set of habitats and therefore culture practices and disturbances.

Experimental designs varied among studies and we crafted our analyses to reflect these designs. First, we addressed the data's structure, a product of studies' sampling regimes. Some studies collected replicate samples taken at the same times or places, and our statistical models accounted for non-independence of these repeated measures. Second, we considered interactions among variables if the study sought a priori to examine interactive effects. This included testing for differential effects of culture methods (i.e., an interaction between treatment presence and treatment type) and effects of culture re-establishment in before-after-control-impact (BACI) studies (Green, 1979). BACI studies follow a design template that monitors many sites. Some locations were restored (here, this refers to implementing culture) and some were not. All locations were monitored before and after restoration. Statistically, we tested for an effect of culture re-establishment on invertebrates by (1) assigning locations to reference (no culture) or restoration (culture re-established) groups and observations to time periods before or after culture, and (2) testing for an interaction between restoration and time statuses. This interactive effect measured change over time unique to restored locations, thus testing for an effect of re-establishing culture.

We used permutational multivariate analyses of variance (PERMANOVA) using Bray-Curtis dissimilarity matrices to test for effects of culture on invertebrate species composition (McArdle \& Anderson 2001). Before tests, we $\log +1$ transformed the data to place abundances across taxa on approximately the same scale, allowing compositional differences to be driven by the entire complement of taxa, including less abundant species. When studies followed a blocked design whereby treatments were nested in blocks of sites (e.g., multiple sites, each sampled at culture vs. no culture locations) or blocks of times (e.g., culture vs. no culture sampled at one site repeatedly over multiple days), we constrained permutations to only use observations collected from the 
same sites and times to isolate effects related to culture from variation attributable to time and space. Because composition varied among sites at the species level, we binned taxa into higher organizational classifications (e.g., order) to visualize patterns among strata in the synthetic study that observed many sites.

We used linear models and their extensions to test for effects of culture on invertebrate counts, richness, and Shannon's diversity. In the synthetic analysis, the explanatory variables were the type of habitat (eelgrass, off-bottom culture, on-bottom culture, or bare) and each combination of date and habitat within a site, which was a random effect to account for nonindependence of observations from the same places and times. Models fit untransformed count data to a negative binomial distribution, which is the standard distribution for ecological count data because it accounts for responses characterized by variances that exceed means (Zuur et al., 2009). We fit richness and diversity metrics to normal distributions because their data were distributed normally. To quantify observations from individual studies, we built models to reflect the unique design of each study and we list the parameters specific to each study (see Results). Often, site and time are accounted for using random effects; however, we parameterized them as fixed effects in some studies where there were a small number of levels (individual dates and times) characterizing their variables following Bolker et al. (2009). However, in studies where there were multiple rounds of sampling on the same sites, we treated combinations of site and date as random effects to account for non-independence of measurements taken at the same time and place, similar in approach with the synthetic analyses. Analyses occurred in R (R Core Team, 2020) using the packages lme4 (Bates et al., 2019; Vegan (Oksanen et al., 2020).

\section{Results}

Synthetic analysis: differential effects of culture on epibenthic invertebrate assemblages

Combining all comparable observations of epibenthic invertebrates across studies, assemblage composition differed among eelgrass, off-bottom, bottom, and bare habitats (Fig. 2, Results-Supplemental Material, Table S1-Supplementary Material, Figure S1-
Supplementary Material). The most common taxa by far were epibenthic harpacticoid copepods Harpacticoida, which comprised a larger portion of the invertebrate assemblage across eelgrass to off-bottom culture (which also included eelgrass) to bottom culture to bare habitats. This pattern was generally coherent among individual sites, although there were some sites with slightly different patterns among habitat types (e.g., Humboldt Bay, Kiket Lagoon) and with unique assemblages (e.g., Turners Bay).

Examining univariate metrics of the assemblage, invertebrates were more abundant in eelgrass and offbottom culture, which also included eelgrass, compared to bare and bottom culture habitats (Fig. 3; Table S2-Supplemental Material). Taxa richness was greater in eelgrass than bottom culture and bare habitats. Taxa diversity was (1) greater in eelgrass than bottom culture and bare habitats and (2) greater in off-bottom culture than bottom culture habitats. Differences in abundance were substantial, with invertebrate abundance on eelgrass and off-bottom culture sites (which also included eelgrass) often more than ten times higher than bare and bottom culture sites. Models indicated that relative to eelgrass, invertebrates in off-bottom culture, bottom culture, and bare habitats were (A) 106\%, 19\%, and $13 \%$ as abundant, (B) $90 \%, 64 \%$, and $59 \%$ as rich, and (C) 103\%, 73\%, and $79 \%$ as diverse, respectively.

\section{Pacific oyster longline study}

The four estuaries had very different harpacticoid copepod assemblage compositions (Fig. S2-Supplemental Material). There was little commonality among the several harpacticoid taxa that were most abundant at each study site. Assemblage composition and invertebrate abundance, but not richness or diversity, varied significantly among strata (Fig. S3-Supplemental Material, Tables S1, S2). Examining all sites on aggregate, invertebrate abundances were greater in eelgrass than under Pacific oyster longline aquaculture (Tukey test: $P=0.05$ ), with models indicating $31 \%$ lower abundance in aquaculture. Given the substantial geographic range of sites, we explored patterns across sites, finding that the pattern of greater abundance in eelgrass than oyster strata was most apparent in Tillamook and Willapa Bays, which were also the sites inhabited by greater abundances of invertebrates overall. There were no 

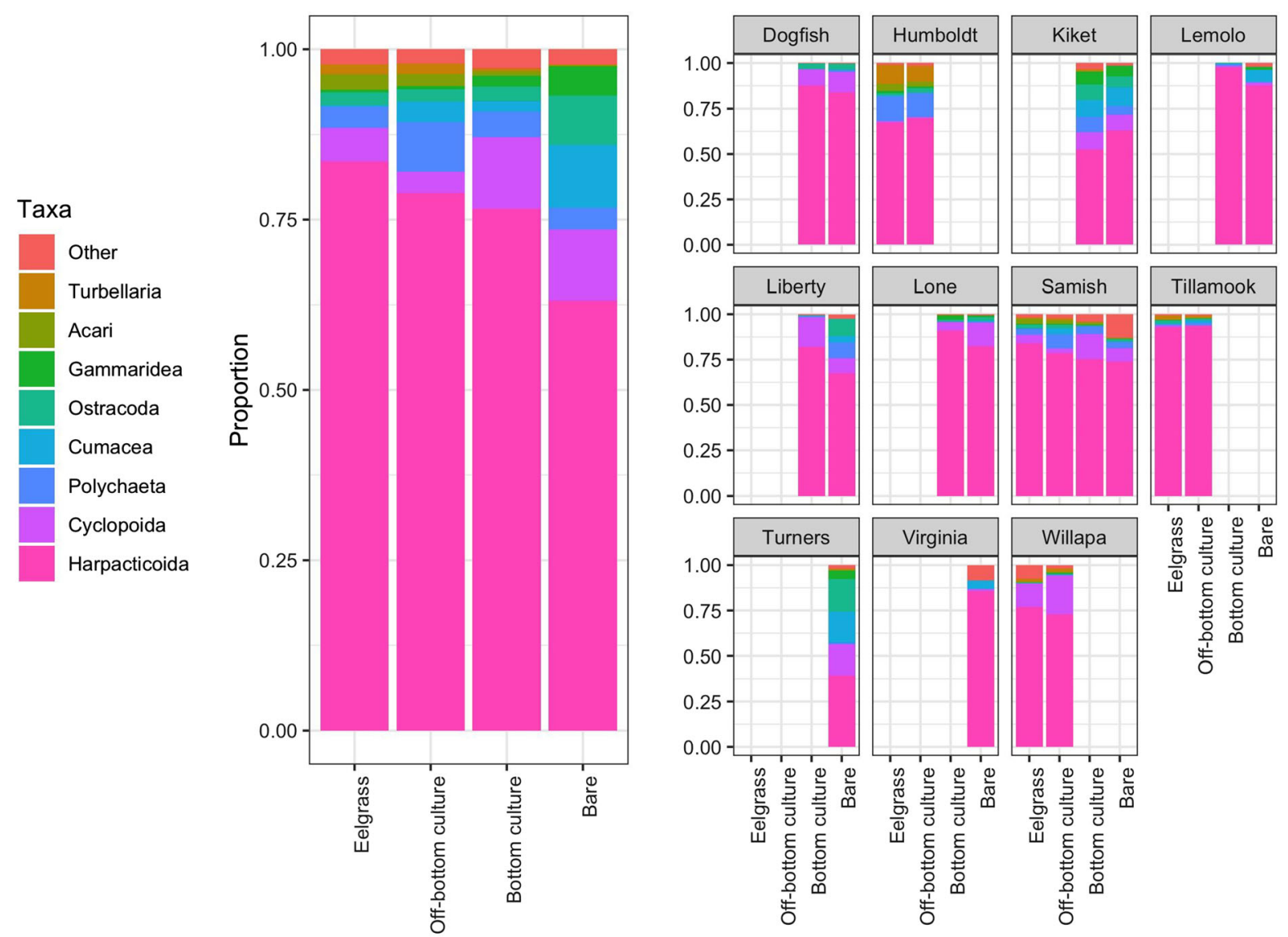

Fig. 2 Composition of invertebrate taxa compared across habitat types. All observations combined (left) and observations faceted by site (right)
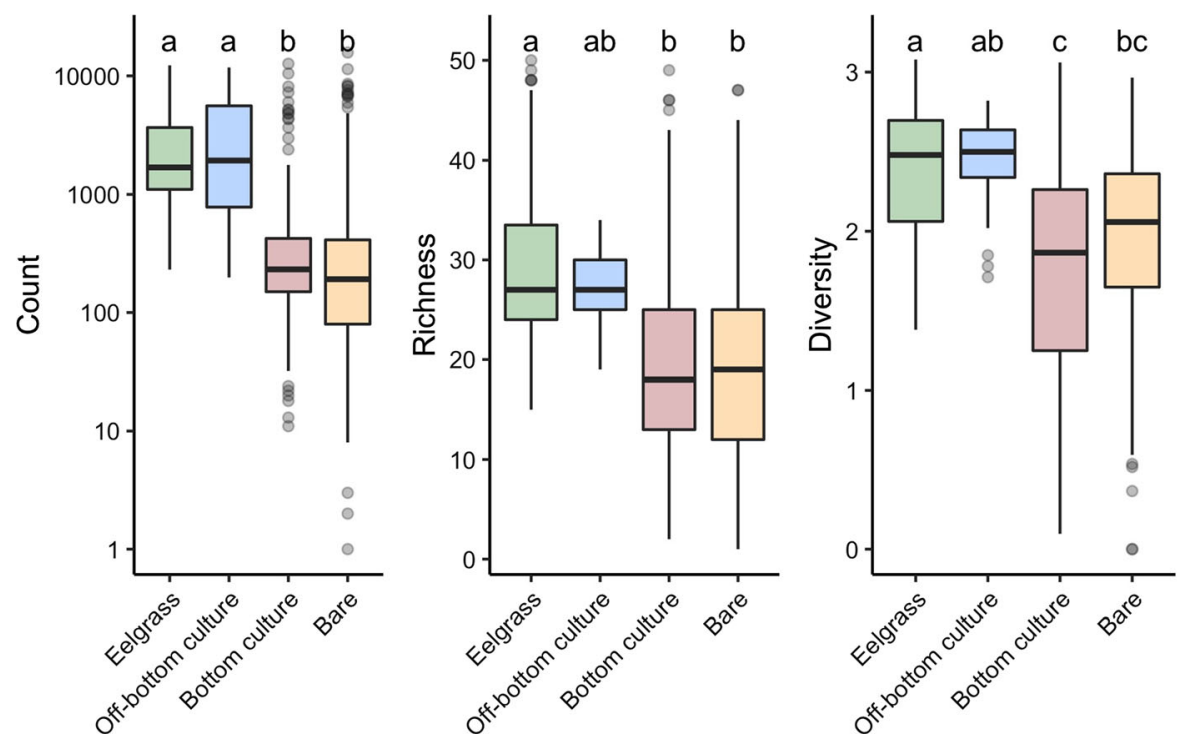

Fig. 3 Counts, richness, and diversity of invertebrates compared across strata from all studies sampling epibenthic invertebrates 
consistent, statistically significant differences in richness or diversity among strata. However, in Tillamook and Willapa Bays, richness peaked in edge strata and diversity increased from eelgrass to edge to oyster strata. In Humboldt Bay, richness and diversity were lowest in edge strata. In Samish Bay, richness was relatively high in oyster strata and diversity decreased from eelgrass to edge to oyster strata.

Pacific oyster flipbag vs. longline study

Assemblage composition differences were significantly different among strata, between aquaculture methods, and differences among strata were influenced by the aquaculture method (Table S1-Supplemental Material). In particular, harpacticoid copepod assemblages were different, with the flipbag culture site being dominated by Tachidius triangularis Shen and Tai, 1963 and Leimia vaga Willey, 1923 and the longline culture site by Tisbe spp. and several other taxa (Fig. S4-Supplemental Material). At the longline culture site, Tisbe spp. had higher relative abundances at the edge and eelgrass strata compared to the culture strata. Assemblage composition differed among strata, between aquaculture methods, and differences among strata were influenced by the aquaculture method (Table S1-Supplemental Material). Patterns in invertebrate counts, richness, and diversity among strata and aquaculture methods were complex (Fig. S5-Supplemental Material). Invertebrate counts did not vary significantly among strata or aquaculture methods (Table S2-Supplemental Material). Richness was not significantly different among strata, but was significantly higher in longline aquaculture, with models indicating 15-16\% lower richness in longline aquaculture, depending on strata. Diversity was significantly higher in oyster aquaculture than eelgrass (Tukey test: $P=0.01$ ), and diversity was higher in longline aquaculture than flipbag aquaculture.

Pacific oyster shell introduction study

Assemblage composition differed between shell and mud substrates (Table 1-Supplemental Material). The mud stratum had higher relative abundances of the harpacticoid copepod taxa Diarthrodes spp. and Danielssenia typica Boeck, 1872, and the shell stratum had higher abundance of Ectinosomatidae
(Fig. S6-Supplemental Material). Invertebrate abundance and richness were significantly higher on shell than mud substrate (Fig. S7-Supplemental Material, Table S2-Supplemental Material). Diversity did not vary significantly between substrates. Models indicated that, on shell hash relative to mud, abundances were $76 \%$ higher and richness was $24-71 \%$ higher depending on the sites and dates.

Olympia oyster BACI study one

Attempts to re-establish Olympia oysters influenced invertebrate assemblage composition (Table S1Supplemental Material). However, changes in proportional contributions of abundant taxa appeared to be more related to time period sampled rather than shell placement (Fig. S8-Supplemental Material). For example, the abundant harpacticoid copepod taxon Tisbe spp. increased in relative abundance post treatment at both shell and reference strata. An effect of oyster re-establishment would be indicated by a statistically significant parameter estimate for the interaction between treatment (control/impact) and phase (before/after). Oyster re-establishment did not influence abundance or richness, but did appear to lower diversity (Fig. S9-Supplemental Material, Table S2-Supplemental Material). Models indicated that oyster re-establishment reduced invertebrate diversity by $17 \%$. Notably, this pattern appeared to be driven by an increase in diversity on reference sites after oyster re-establishment that did not occur on sites where oysters were re-established.

\section{Olympia oyster BACI study two}

Re-establishing Olympia oysters significantly influenced invertebrate assemblage composition (Table S1-Supplemental Material). At the control (no oyster addition) site, proportions of relatively abundant taxa were similar in before-and-after samples (Fig. S10-Supplemental Material). At the two sites where Olympia oysters were re-established, prominent taxa differed in relative abundance between the sites prior to re-establishment. At the Kiket Lagoon site the harpacticoid copepods Dactylopusia vulgaris Sars, 1905, and Sarsamphiascus sp. varians group were more abundant before oyster addition while the harpacticoid Tisbe spp. was more abundant after oyster addition. At the Lone Tree Lagoon site, the 
cyclopoid copepod Cyclopina spp. was more abundant before oyster addition. Overall, however, there were no significant interactions between treatment (control/ impact) and phase (before/after), indicating that abundance, richness, and diversity across sites did not change due to oyster re-establishment (Fig. S11Supplemental Material, Table S2-Supplemental Material).

Manila clam eelgrass, sand, and anti-predator netting

In the epibenthic pump samples from swept and unswept anti-predator netting sites, and at eelgrass and unvegetated reference strata, there were many taxa that contributed to the assemblage (Fig. S12-Supplemental Material). The harpacticoid taxa Ectinosomatidae and Harpacticus obscurus group Scott, 1895, were the most abundant taxa in the eelgrass stratum, while the bare sand and swept net strata were inhabited by more Sarsamphiascus sp. A, Paralaophonte pacifica Lang, 1965, and Ameiridae. The most abundant taxon at the un-swept site was the cyclopoid copepod Cyclopina spp. Assemblage composition differences were statistically significant, with eelgrass differing most from sand areas (Table S1-Supplemental Material). Invertebrate counts and diversity did not significantly vary among strata (Fig. S13-Supplemental Material, Table S2-Supplemental Material). Richness was highest on eelgrass, and was significantly lower on sand than eelgrass (Tukey test: $P=0.04)$. Models indicated richness on sand was 16-23\% lower than eelgrass depending on the date.

Benthic study: Manila clam unfarmed vs. hand harvest vs. mechanical harvest

In the only study to examine benthic infauna, the invertebrate assemblage was dominated by oligochaete and nematode worms (Fig. S14-Supplemental Material). Proportions of these two taxa were higher on farmed areas compared to adjacent eelgrass. Proportions of the tanaid crustacean Leptochelia sp. and the polychaete worm Exogone lourei Berkeley \& Berkeley, 1938, were higher in the eelgrass area. Assemblage composition differences among strata were statistically significant and most apparent between unfarmed areas and areas after mechanical harvesting (Table S1-Supplemental Material).
Invertebrate counts, richness, and diversity were significantly higher on unfarmed areas compared to farmed areas (Fig. S15-Supplemental Material, Table S2-Supplemental Material). Abundances (Tukey tests: $P=0.003,0.001$, and 0.01 , respectively) and richness (Tukey tests each $P<0.0001$ ) were significantly higher in unfarmed areas compared to areas before harvest, areas after hand harvest, and areas after mechanical harvest. Diversity was significantly higher in unfarmed areas compared to areas after mechanical harvest (Tukey test: $P=0.04$ ). Compared to unfarmed areas, models indicated invertebrate (A) abundances were 55\% lower in areas before harvest, $63 \%$ lower in areas after hand harvest, and 55\% lower in areas after mechanical harvest, (B) richness was $23 \%$ lower in areas before harvest, $33 \%$ lower in areas after hand harvest, and 34\% lower after mechanical harvest, and (C) diversity was $25 \%$ lower in areas after mechanical harvest.

\section{Discussion}

We compared invertebrate assemblages among habitats that were and were not modified by bivalve cultivation (summarized in Table 2). Synthesizing observations of epibenthic invertebrates across six studies, we found that assemblages differed among habitat types. The predominant taxa were harpacticoid copepods, which contributed increasingly to invertebrate assemblage composition from bare (open and unstructured sand and mud) to bottom culture to offbottom culture to eelgrass habitats. Additionally, we found that invertebrates were generally (i.e., with some exceptions in specific habitat comparisons) more abundant, rich, and diverse in eelgrass and off-bottom culture habitats (which included eelgrass) as compared to less structured on-bottom and bare (mud, sand) habitats (that did not include eelgrass). Many of the invertebrates that were more abundant in eelgrass and off-bottom culture habitats, including harpacticoid copepods, are common in the diets of fish (e.g., smelt, salmon) and are thought to promote their growth as juveniles (Miller et al., 1976; Simenstad et al., 1982; Wissmar \& Simenstad, 1988; Morley et al., 2012; Munsch et al., 2015). Invertebrates were also more abundant in eelgrass than in open, unstructured mud and sand habitat. This is consistent with our current understanding that eelgrass provides important 
Table 2 Summary of results from all studies (ns: no statistically significant findings; X: presence of statistically significant differences in composition)

\begin{tabular}{|c|c|c|c|c|c|c|}
\hline Study & Main comparison & Composition & Counts & Richness & Diversity & Figures \\
\hline Synthetic analysis & $\begin{array}{l}\text { Bare vs. bottom } \\
\text { culture vs. off- } \\
\text { bottom culture vs. } \\
\text { eelgrass }\end{array}$ & $X$ & $\begin{array}{l}\text { Eelgrass \& off- } \\
\text { bottom } \\
\text { culture }>\text { bare } \\
\& \text { bottom } \\
\text { culture }\end{array}$ & $\begin{array}{l}\text { Eelgrass }>\text { bare } \\
\& \text { bottom } \\
\text { culture }\end{array}$ & $\begin{array}{l}\text { Eelgrass }>\text { bare \& } \\
\text { bottom culture; } \\
\text { off-bottom } \\
\text { culture }>\text { bottom } \\
\text { culture }\end{array}$ & 3 \\
\hline Pacific oyster longline & $\begin{array}{l}\text { Oyster vs. edge vs. } \\
\text { eelgrass }\end{array}$ & $X$ & Eelgrass $>$ oyster & ns & ns & $\mathrm{S} 2, \mathrm{~S} 3$ \\
\hline $\begin{array}{l}\text { Pacific oyster flipbag } \\
\text { vs. longline }\end{array}$ & $\begin{array}{l}\text { Differential effects } \\
\text { of flipbag vs. } \\
\text { longline culture }\end{array}$ & $X$ & ns & ns & ns & S4, S5 \\
\hline $\begin{array}{l}\text { Pacific oyster shell } \\
\text { introduction }\end{array}$ & Shell vs. mud & $X$ & Shell $>$ mud & Shell $>$ mud & Shell $>$ mud & $\begin{array}{l}\text { S8, } \\
\text { S10 }\end{array}$ \\
\hline $\begin{array}{l}\text { Olympia oyster BACI } \\
\text { one }\end{array}$ & $\begin{array}{l}\text { Re-establishment } \\
\text { effects }\end{array}$ & $X$ & ns & ns & Reduced & $\begin{array}{l}\text { S10, } \\
\text { S11 }\end{array}$ \\
\hline $\begin{array}{l}\text { Olympia oyster BACI } \\
\text { two }\end{array}$ & $\begin{array}{l}\text { Re-establishment } \\
\text { effects }\end{array}$ & $X$ & ns & ns & ns & $\begin{array}{l}\mathrm{S} 12 \\
\mathrm{~S} 13\end{array}$ \\
\hline $\begin{array}{l}\text { Manila clam eelgrass, } \\
\text { sand, and anti- } \\
\text { predator netting }\end{array}$ & $\begin{array}{l}\text { Eelgrass vs. swept } \\
\text { anti-predator } \\
\text { netting vs. un- } \\
\text { swept anti- } \\
\text { predator netting }\end{array}$ & $X$ & ns & Eelgrass $>$ sand & $\mathrm{ns}$ & S6, S7 \\
\hline $\begin{array}{l}\text { Benthic study: Manila } \\
\text { clam unfarmed vs. } \\
\text { hand harvest vs. } \\
\text { mechanical harvest }\end{array}$ & $\begin{array}{l}\text { Unfarmed vs. } \\
\text { before harvest vs. } \\
\text { after hand harvest } \\
\text { vs. after mech } \\
\text { harvest }\end{array}$ & $X$ & $\begin{array}{l}\text { Unfarmed }>\text { all } \\
\text { farmed strata }\end{array}$ & $\begin{array}{l}\text { Unfarmed }>\text { all } \\
\text { farmed strata }\end{array}$ & $\begin{array}{l}\text { Unfarmed }>\text { after } \\
\text { mech harvest }\end{array}$ & $\begin{array}{l}\text { S14, } \\
\text { S15 }\end{array}$ \\
\hline
\end{tabular}

Figures beginning with $\mathrm{S}$ refer to supplemental figures

habitat for some secondary consumers because it produces an abundance of prey (Beck et al., 2001; Kennedy et al., 2018).

Results of individual studies suggested that, compared to the distinction between eelgrass habitat and off-bottom culture that included eelgrass versus less structured on-bottom culture and open sand or mud, only minor differences in invertebrate abundance, richness, or diversity could be detected between various culture techniques or the re-establishment of native oysters. The exception to this was that benthic invertebrates tended to be less abundant, rich, and diverse in areas that clam culture did not take place (note: diversity was only significantly lower in unfarmed vs. mechanically farmed areas). Additionally, we found widespread evidence across studies that invertebrate assemblage composition differed among sites of varying bivalve cultural influence.
Our goal was to examine findings from studies that may indicate effects of aquaculture and native oyster re-establishment on invertebrate assemblages along the US west coast. Ideally, our results will guide future studies seeking to better understand mechanisms that cause change in nearshore ecosystems. In general, our findings, those from other systems (e.g., McKindsey et al., 2011), and a broader knowledge that artificial structures influence nearshore invertebrate assemblages (e.g., Heery et al., 2017), suggest that bivalve culture can alter invertebrate assemblages, but patterns are often mediated by specific ecological, geographic, and culture methodological contexts, and apparent effects vary in magnitude and direction (Dumbauld et al., 2009).

Some invertebrate responses that we reported were similar to previous work. Similar to our study, Coe (2019) found that epibenthic and benthic invertebrates were more abundant in eelgrass and line cultured 
oyster habitats with eelgrass present than in nearby unstructured mudflats. Likewise, Hosack et al. (2006) found that both eelgrass and on-bottom habitats where both Pacific oysters and some eelgrass were present ( $4.6 \%$ cover) were inhabited by greater abundances of epibenthic invertebrates than mudflats. This study and ours are consistent with the hypothesis that culture's structure in places near or overlapping productive eelgrass may benefit invertebrates by creating habitats with low flows and attachment points for the invertebrates and some of their food. Indeed, novel but complex structures in intertidal areas can provide habitats for the epibenthic invertebrates observed in our study (Cordell et al., 2017b). A remaining question is whether the shade cast by off-bottom culture reduces epibenthic invertebrate abundances, as has been observed elsewhere probably by reducing the algal food for these invertebrates (Cordell et al., 2017a). Examining benthic invertebrates, (Griffiths et al., 2006) found that shorelines protected from clam harvest were inhabited by a different benthic assemblage compared to harvested shorelines, including greater richness of benthic invertebrates. They also found that disturbance from digging reduced benthic invertebrate abundances. This study and ours are consistent with the hypothesis that culturing and harvesting burrowing species can impact benthic invertebrates through pulse disturbance, chronic disturbance, and competition for space.

Our study would benefit from further, nuanced research to expand our understanding of ecological effects of shellfish culture. We elected to use similar analyses across many studies to investigate whether there were any general patterns across regions and culture techniques. A complementary and necessary approach moving forward will include in-depth explorations of localized ecologies that explain differences in invertebrate assemblages attributable to culture. Specifically, long-term (e.g., 5-10 years) studies may reveal whether changes (e.g., Olympia oyster re-establishment) are temporary and on what time scales they occur. Indeed, the BACI studies in particular would have benefited from longer longitudinal perspectives to detect patterns by quantifying assemblages several years before and after oysters were re-established. Also, larger scale (i.e., seascape) studies that encompass a variety of aquatic and terrestrial habitats that influence the ecology and environment of the study area may be informative.
Notably, we examined localized responses of invertebrates to habitat types, but off-bottom culture also included an overlapping presence of eelgrass while bottom culture did not; thus, this study does not test for differences in invertebrates between natural habitats and habitats that have only off-bottom oyster culture (with no eelgrass). Seascape studies examining source-sink dynamics (e.g., via isotope markers) may reveal the potential for nearshore habitats (e.g., aquaculture, eelgrass) to act as a source of invertebrates that subsidizes surrounding habitats, especially in less productive (e.g., bare) seascapes, or act as a sink for invertebrates (sensu Dealteris et al., 2004; Dumbauld and McCoy 2015). Moreover, surrounding, larger scale habitat mosaics (e.g., backshore vegetation, kelp forests, saltmarshes) may also determine patterns observed on culture sites. Another logical extension of our work would be to examine the influence of bivalve culture on the subsidy of epibenthic and benthic invertebrate prey to higher trophic levels and assess whether culture can provide predator refuge for smaller fish and crabs. These consumers include a global range of culturally and economically important species that use shallow waters as nurseries and target bottom-dwelling invertebrate prey (e.g., Pacific salmon Oncorhynchus spp., Simenstad et al., 1982; stone flounder Platichthys bicoloratus (Basilewsky, 1855; Yamashita et al., 2003) that are compromised along heavily modified shorelines (Morley et al., 2012; Munsch et al., 2015).

In interpreting our findings, it is important to consider that we employed an exploratory approach that tested for differences in metrics (composition, abundance, richness, diversity) across many studies. Distilling trends from these studies required us to create multiple statistical models tailored to unique study designs, resulting in many comparisons. We reported the summary statistics for each comparison, using the conventional alpha value of 0.05 , because it enabled us to appreciate signals within the noise of large, structured, and unique datasets, but our overarching goal was to examine patterns that emerged from the studies collectively. Given the many comparisons, results of any single comparison should be interpreted cautiously. In addition, it is important to consider that sampling regimes, thus statistical powers, varied among studies. In particular, expansive replication within and across sites is necessary to formulate a robust BACI design, especially considering the 
dynamic nature of populations within habitat patches (Underwood 1994). As the sampling regime of BACI Study Two was more expansive than BACI Study One, we may expect the results of the second BACI study to be more robust. Furthermore, while richness and diversity are often indicative of functional ecosystems (e.g., Schindler et al., 2015) and conducive as metrics in exploratory analyses, there are many additional ecosystem attributes and processes that may more directly indicate habitat value for invertebrates and their consumers (e.g., invertebrate assemblages supporting consumers' ontogenetic diet shifts, the environment's predation risk for consumers being low and conducive to often-risky feeding behavior; colonization dynamics among local invertebrate populations within larger metapopulations that are supported by habitat connectivity and stabilize invertebrate densities; Sheaves et al., 2015).

Understanding the ecological influences of culture used to produce food or restore ecosystems is important considering estuaries and coasts have endured legacies of degradation (Lotze et al., 2006). In the case of food production, the global supply of seafood from aquaculture now exceeds that of capture fisheries, which have remained stagnant, suggesting that aquatic resources will be increasingly sourced from aquaculture (FAO 2016). This solution is tentatively appealing because the environmental footprint (e.g., energy, greenhouse gas, acidification potential, eutrophication potential) of meat produced from shellfish culture compared to other sources (e.g., livestock, capture fisheries) is relatively low, especially considered in the context of feeding a global population via agriculture, other cultured species, and wild fisheries (Hilborn et al., 2018). Our results and those of others suggest that the influences of bivalve shellfish culture practices on localized invertebrate assemblages range from positive (e.g., abundance and richness effects of introducing shell hash to mudflats), to undetectable (e.g., abundance effects of introducing native oysters to bare habitats), to negative (e.g., abundance, richness, and diversity effects of Manila clam harvest). A fruitful area for further work may then be to further investigate apparently positive or neutral scenarios from mechanistic, seascape (i.e., accounting for spatial arrangement and scale), and ecosystem-level (e.g., predator-prey interactions) perspectives. This may enable people to anticipate responses that are generalizable across ecosystems and make decisions that optimize outcomes across food and ecosystem considerations. Overall, there appears to be potential for coastal communities to restore extirpated bivalve populations or develop bivalve culture practices that meet objectives to grow food while maintaining nearshore ecosystems' fundamental, localized processes supported by robust invertebrate assemblages.

Acknowledgements Swinomish gratefully acknowledges L. Loomis and the Swinomish Senate for fundamental support, and C. Greiner, S. Grossman, L. Hunter, and J. McArdle for field and lab work. We thank B. Ferriss, A. Trainer, G. Williams, and two anonymous reviewers for helpful critiques that improved the manuscript, and O. Stefankiv for creating the map figure, and C. Levy, E. Morgan, R. Oxborrow, and M. Caputo for field work.

Funding NOAA Fisheries West Coast Regional Office and Office of Aquaculture, US Fish and Wildlife Service Tribal Wildlife Grant F14AP00495-0001-0000; Conservation, Research and Education Opportunities International; EPA grant PA-00J322-01; the Pacific Shellfish Institute, and the Puget Sound Restoration Fund.

Data availability Available upon request to the authors.

\section{Compliance with ethical standards}

Conflict of interest The authors declare that they have no conflicts of interest.

Open Access This article is licensed under a Creative Commons Attribution 4.0 International License, which permits use, sharing, adaptation, distribution and reproduction in any medium or format, as long as you give appropriate credit to the original author(s) and the source, provide a link to the Creative Commons licence, and indicate if changes were made. The images or other third party material in this article are included in the article's Creative Commons licence, unless indicated otherwise in a credit line to the material. If material is not included in the article's Creative Commons licence and your intended use is not permitted by statutory regulation or exceeds the permitted use, you will need to obtain permission directly from the copyright holder. To view a copy of this licence, visit http://creativecommons.org/licenses/by/4.0/.

\section{References}

Adams, A., Reeve, L. 1850. Mollusca. In A. Adams (ed.), The zoology of the voyage of H.M.S. Samarang, under the command of Captain Sir Edward Belcher, C.B., F.R.A.S., F.G.S., during the years 1843-1846. Reeve \& Benham, London.

Basilewsky, S., 1855. Ichthyographia Chinae Borealis. Nouveaux mémoires de la Société impériale des naturalistes de Moscou 10: 215-263. 
Bates, D., M. Maechler, B. Bolker \& S. Walker, 2019. Fitting linear mixed-effects models using lme4. J Stat Softw 67: $1-48$.

Beck, M. W., Heck, K. L., Able, K. W., Childers, D. L., Eggleston, D. B., Gillanders, B. M.,... \& Orth, R. J. 2001. The identification, conservation, and management of estuarine and marine nurseries for fish and invertebrates: a better understanding of the habitats that serve as nurseries for marine species and the factors that create site-specific variability in nursery quality will improve conservation and management of these areas. Bioscience 51: 633-641

Berkeley, E. \& C. Berkeley, 1938. Notes on Polychaeta from the coast of western Canada. II. Syllidae. Annals and Magazine of Natural History Series 11: 33-49.

Boeck, A., 1872. Nye Slaegter og Arter af Saltvands-Copepoder. Forhandlinger i Videnskabs-Selskabet i Kristiana 1872: 35-60.

Bolker, B. M., M. E. Brooks, C. J. Clark, S. W. Geange, J. R. Poulsen, M. H. H. Stevens \& J. S. S. White, 2009. Generalized linear mixed models: a practical guide for ecology and evolution. Trends in Ecology \& Evolution 24: 127-135.

Carpenter, P. P., 1864. Supplementary report on the present state of our knowledge with regard to the Mollusca of the west coast of North America. Reports of the British Association for the Advancement of Science 33(1863): 517-686.

Coe, H. C. Effects of longline oyster aquaculture on benthic invertebrate communities in Humboldt Bay, California. M.S. Thesis. Humboldt State University.

Cordell, J. R., S. H. Munsch, M. E. Shelton \& J. D. Toft, 2017a. Effects of piers on assemblage composition, abundance, and taxa richness of small epibenthic invertebrates. Hydrobiologia 802: 211-220.

Cordell, J. R., Toft, J. D., Munsch, S. H., \& Goff, M. 2017b. Benches, beaches, and bumps: how habitat monitoring and experimental science can inform urban seawall design. In Living Shorelines (pp. 421-438). CRC Press.

D’Aguillo, M. C., A. S. Harold \& T. L. Darden, 2014. Diet composition and feeding ecology of the naked goby Gobiosoma bosc (Gobiidae) from four western Atlantic estuaries. Journal of Fish Biology 85: 355-373.

Dealteris, J. T., B. D. Kilpatrick \& R. B. Rheault, 2004. A comparative evaluation of the habitat value of shellfish aquaculture gear, submerged aquatic vegetation and a nonvegetated seabed. Journal of Shellfish Research 23: 867-874.

Dumbauld, B. R., J. L. Ruesink \& S. S. Rumrill, 2009. The ecological role of bivalve shellfish aquaculture in the estuarine environment: a review with application to oyster and clam culture in West Coast (USA) estuaries. Aquaculture 290: 196-223.

Dumbauld, B. R. \& L. M. McCoy, 2015. Effect of oyster aquaculture on seagrass Zostera marina at the estuarine landscape scale in Willapa Bay, Washington (USA). Aquaculture Environment Interactions 7: 29-47.

FAO, 2016. Contributing to food security and nutrition for all. Food and Agriculture Organization of the United Nations, Rome.

Forrest, B. M., N. B. Keeley, G. A. Hopkins, S. C. Webb \& D. M. Clement, 2009. Bivalve aquaculture in estuaries: review and synthesis of oyster cultivation effects. Aquaculture 298: 1-15.

Gallardi, D., 2014. Effects of bivalve aquaculture on the environment and their possible mitigation: a review. Fisheries and Aquaculture Journal. https://doi.org/10.4172/21503508.1000105 .

Gee, J. M., 1989. An ecological and economic review of meiofauna as food for fish. Zoological Journal of the Linnean Society 96: 243-261.

Green, R. H., 1979. Sampling design and statistical methods for environmental biologists. Wiley, New York.

Griffiths, J., M. N. Dethier, A. Newsom, J. E. Byers, J. J. Meyer, F. Oyarzun \& H. Lenihan, 2006. Invertebrate community responses to recreational clam digging. Marine Biology 149: 1489-1497.

Heery, E. C., Bishop, M. J., Critchley, L. P., Bugnot, A. B., Airoldi, L., Mayer-Pinto, M.,... \& Komyakova, V. 2017. Identifying the consequences of ocean sprawl for sedimentary habitats. Journal of Experimental Marine Biology and Ecology 492: 31-48

Hilborn, R., J. Banobi, S. J. Hall, T. Pucylowski \& T. E. Walsworth, 2018. The environmental cost of animal source foods. Frontiers in Ecology and the Environment 16: 329-335.

Hosack, G. R., B. R. Dumbauld, J. L. Ruesink \& D. A. Armstrong, 2006. Habitat associations of estuarine species: comparisons of intertidal mudflat, seagrass (Zostera marina), and oyster (Crassostrea gigas) habitats. Estuaries and Coasts 29: 1150-1160.

Hudson, B., D. Cheney, B. Dumbauld, J. Cordell, F. TomasNash, S. Kramer, K. Houle, A. Suhrbier, M. Middleton, J. Toft, J. Kralj, D. Mercer, L. Clarke, K. Meuthing, C. Mack \& J. Minch, 2018. Quantification of functional relationships between shellfish culture and seagrass in US west coast estuaries to inform regulatory decisions. Final Report for NOAA Saltonstall-Kennedy Program Award No. NA15NMF4270318.

Kennedy, L. A., F. Juanes \& R. El-Sabaawi, 2018. Eelgrass as valuable nearshore foraging habitat for juvenile Pacific salmon in the early marine period. Marine and Coastal Fisheries 10: 190-203.

Lang, K., 1965. Copepoda harpacticoida from the californian pacific coast. Kungliga Svenska Vetenskapsakademiens Handlingar 10: 1-560.

Linnaeus, C. 1753. Species plantarum, exhibentes plantas rite cognitas ad genera relatas cum differentiis specificis, nominibus trivialibus, synonymis selectis, locis natalibus, secundum systema sexuale digestas. Stockholm

Lotze, H. K., Lenihan, H. S., Bourque, B. J., Bradbury, R. H., Cooke, R. G., Kay, M. C.,... \& Jackson, J. B. 2006. Depletion, degradation, and recovery potential of estuaries and coastal seas. Science 312: 1806-1809.

McArdle, B. H. \& M. J. Anderson, 2001. Fitting multivariate models to community data: a comment on distance-based redundancy analysis. Ecology 82: 290-297.

McKindsey, C. W., P. Archambault, M. D. Callier \& F. Olivier, 2011. Influence of suspended and off-bottom mussel culture on the sea bottom and benthic habitats: a review. Canadian Journal of Zoology 89: 622-646.

Miller, B. S., Simenstad, C. A., Moulton, L. R. 1976. Puget Sound Baseline Program: Nearshore fish survey. 
University of Washington College of Fisheries technical report to Washington State Department of Ecology No. 75-017.

Morley, S. A., J. D. Toft \& K. M. Hanson, 2012. Ecological effects of shoreline armoring on intertidal habitats of a Puget Sound urban estuary. Estuaries and Coasts 35: 774-784.

Munsch, S. H., J. R. Cordell \& J. D. Toft, 2015. Effects of seawall armoring on juvenile Pacific salmon diets in an urban estuarine embayment. Marine Ecology Progress Series 535: 213-229.

Nehlsen, W., J. E. Williams \& J. A. Lichatowich, 1991. Pacific salmon at the crossroads: stocks at risk from California, Oregon, Idaho, and Washington. Fisheries 16: 4-21.

Nunn, A. D., L. H. Tewson \& I. G. Cowx, 2012. The foraging ecology of larval and juvenile fishes. Reviews in Fish Biology and Fisheries 22: 377-408.

Oksanen, J. F., Blanchet, F. G., Kindt, R., Legendre, P., Minchin, P. R., O'Hara, R. B., Simpson, G. L., Solymos, P. Stevens, M. H. M., \& Wagner H. 2020. Vegan: Community Ecology Package. R package version 2.5-6. https://cran.rproject.org/package=vegan

Powers, M. J., C. H. Peterson, H. C. Summerson \& S. P. Powers, 2007. Macroalgal growth on bivalve aquaculture netting enhances nursery habitat for mobile invertebrates and juvenile fishes. Marine Ecology Progress Series 339: 109-122.

Pritchard, C., A. Shanks, R. Rimler, M. Oates \& S. Rumrill, 2015. The Olympia oyster Ostrea lurida: recent advances in natural history, ecology, and restoration. Journal of Shellfish Research 34: 259-271.

R Core Team, 2020. R: a language and environment for statistical computing. R Foundation for Statistical Computing, Vienna.

Ruesink, J. L., H. S. Lenihan, A. C. Trimble, K. W. Heiman, F. Micheli, J. E. Byers \& M. C. Kay, 2005. Introduction of non-native oysters: ecosystem effects and restoration implications. Annual Review of Ecology, Evolution, and Systematics 36: 643-689.

Sars, G. O., 1905. Copepoda Harpacticoida. Parts IX \& X. Thalestridae (continued). An Account of the Crustacea of Norway, with short descriptions and figures of all the species. Bergen Museum 5: 109-132.

Saurel, C., J. G. Ferreira, D. Cheney, A. Suhrbier, B. Dewey, J. Davis \& J. Cordell, 2014. Ecosystem goods and services from Manila clam culture in Puget Sound: a modelling analysis. Aquaculture Environment Interactions 5: 255-270.

Schindler, D. E., J. B. Armstrong \& T. E. Reed, 2015. The portfolio concept in ecology and evolution. Frontiers in Ecology and the Environment 13: 257-263.

Scharf, F. S., J. A. Buckel, K. A. Rose, F. Juanes \& J. H. Cowan Jr., 2006. Effects of variable prey and cohort dynamics on growth of young-of-the-year estuarine bluefish: evidence for interactions between spring-and summer-spawned cohorts. Transactions of the American Fisheries Society 135: 1266-1289.
Scott, T., 1895. Additions to the fauna of the Firth of Forth. Part VII. Annual Report of the Fishery Board for Scotland, Edinburgh 13: 165-173.

Selleslagh, J., H. Blanchet, G. Bachelet \& J. Lobry, 2015. Feeding habitats, connectivity and origin of organic matter supporting fish populations in an estuary with a reduced intertidal area assessed by stable isotope analysis. Estuaries and Coasts 38: 1431-1447.

Sheaves, M., R. Baker, I. Nagelkerken \& R. M. Connolly, 2015. True value of estuarine and coastal nurseries for fish: incorporating complexity and dynamics. Estuaries and Coasts 38: 401-414.

Shen, C. J. \& A. Y. Tai, 1963. On five new species, a new subgenus and a new genus of freshwater Copepoda (Harpacticoida) from the delta of the Pearl River, South China. Acta Zoologica Sinica 15: 417-432.

Shumway, S. E., Davis, C., Downey, R., Karney, R., Kraeuter, J., Parsons, J.... \& Wikfors, G. 2003. Shellfish aquaculture-in praise of sustainable economies and environments. World Aquaculture 34: 8-10.

Simenstad, C. A., Fresh, K. L., \& Salo, E. O. 1982. The role of Puget Sound and Washington coastal estuaries in the life history of Pacific salmon: an unappreciated function. In Estuarine Comparisons (pp. 343-364). Academic Press.

Simenstad, C. A. \& K. L. Fresh, 1995. Influence of intertidal aquaculture on benthic communities in Pacific Northwest estuaries: scales of disturbance. Estuaries 18: 43-70.

Thunberg C. P. 1793. Tekning och Beskrifning på en stor Ostronsort ifrån Japan. Kongliga Vetenskaps Academiens Nya Handlingar 14: 140-142.

Toft, J. D., J. R. Cordell, C. A. Simenstad \& L. A. Stamatiou, 2007. Fish distribution, abundance, and behavior along city shoreline types in Puget Sound. North American Journal of Fisheries Management 27: 465-480.

Underwood, A. J., 1994. On beyond BACI: sampling designs that might reliably detect environmental disturbances. Ecological Applications 4: 3-15.

White, J., J. L. Ruesink \& A. C. Trimble, 2009. The nearly forgotten oyster: Ostrea lurida Carpenter 1864 (Olympia oyster) history and management in Washington State. Journal of Shellfish Research 28: 43-49.

Willey, A., 1923. Notes on the distribution of free-living Copepoda in Canadian waters. Contributions to Canadian Biology, New Series 1: 303-334.

Wissmar, R. C. \& C. A. Simenstad, 1988. Energetic constraints of juvenile chum salmon (Oncorhynchus keta) migrating in estuaries. Canadian Journal of Fisheries and Aquatic Sciences 45: 1555-1560.

Yamashita, Y., O. Tominaga, H. Takami \& H. Yamada, 2003. Comparison of growth, feeding and cortisol level in Platichthys bicoloratus juveniles between estuarine and nearshore nursery grounds. Journal of Fish Biology 63: 617-630.

Zu Ermgassen, P. S. E., M. D. Spalding, B. Blake, L. D. Coen, B. Dumbauld, S. Geiger, J. H. Grabowski, R. Grizzle, M. Luckenbach, K. McGraw, W. Rodney, J. L. Ruesink, S. P. Powers \& R. Brumbaugh, 2012. Historical ecology with real numbers: past and present extent and biomass of an 
imperilled estuarine habitat. Proceedings of the Royal Society B 279: 3393-3400.

Zuur, A., E. N. Ieno, N. Walker, A. A. Saveliev \& G. M. Smith, 2009. Mixed Effects Models and Extensions in Ecology with R. Springer, New York.
Publisher's Note Springer Nature remains neutral with regard to jurisdictional claims in published maps and institutional affiliations. 